\title{
EFFECT OF SOME PLANT EXTRACTS ON CITRUS MEALY BUG PLANOCOCCUS CITRI (RISSO)
}

\author{
AMANY S. EL-HEFNY, OMNIA M. N. EL-SAHN \\ AND SH.S. YACOUB
}

Plant Protection Research Institute, ARC, Dokki, Giza

(Manuscript received 31 October 2010 )

\begin{abstract}
Pulp of sour orange fruit; Citrus aurantium v. amara extracted in water and petroleum ether, leaves of lantana; Lantana sa/vifolia extracted in acetone and leaves of Herb Robert; Geranium robertianum extracted in water at different concentrations 3,4 and $5 \%$ were tested under laboratory conditions against Citrus mealy bug Planococcus citri (Risso) (Pseudococcidae: Homoptera) which is one of the most wide spread insects infesting horticulture crops either inside or outside greenhouses.

Data demonstrated that sour orange extracted in petroleum ether the highest reduction in the population of the different stages of the mealy bug being $97.01 \%$ after 8 days from treatment with the assayed materials at $5 \%$ concentration. While lantana extract in acetone, pulp of sour orange and leaves of Herb Robert extracted in water achieved intermediate reductions in bug population. Also, $\mathrm{LT}_{50}$ values were determined for the different treatments and it ranged from 2.32 to 3.75 days for leaves of Herb Robert extracted in water and pulp of sour orange extracted in water, respectively.
\end{abstract}

\section{INTRODUCTION}

In order to avoid the hazards caused to the environment due to the repeat use of traditional chemical insecticides that are commonly used. For this, using natural products mainly plant extracts as one of the insect control methods becomes a must which proof to have deletrious effect on target insect El-Sayed (1982), Awadallah et al., (1984).

Sour orange extracts were evaluated in controlling Sesamia cretica Led. (Lepidoptera: Noctuidae), and they found to have toxic effect throughout its different stages Yacoub, et al., (2010)

Citrus mealy bug Planococcus citri (Risso) (Pseudococcidae: Homoptera) is one of the most wide spread mealy bugs infesting horticulture crops cultivated either inside or outside greenhouses.

Damage of this pest appears by sucking plant sap which causes yellowish leaves turning to brown then they dry and fall, due to their toxic saliva. Besides, it secrets the honey dew which is considered a suitable mean for the growth of the sooty mold fungi. Also, it causes malformation to the tips and leaves of the plant and the cottony wax 
secretion of the insect different stages causes a disfigure to the plant, which is considered the fortune of the ornamental.

The present study aimed to assay the efficacy of extracts on Planococcus citrus (Risso) infestation. Also, laboratory studies were contucted to find out $\mathrm{LT}_{50}$ values.

\section{MATERIALS AND METHODS}

A laboratory experiment was conducted to evaluate some plant extracts used in controlling the $P$. citrus infesting croton (Codiaeum sp.) Fam.: Euphorbiaceae

\section{Preparation of material}

Extracts were prepared according to Emara et al., (1994) by adding $500 \mathrm{ml}$ boiling water to $50 \mathrm{gm}$ of grained leaves of Herb Robert, while pulp of sour orange fruit were squeezed without seeds.

Dry Lantana leaves ( $50 \mathrm{gm}$ ) were prepared by adding $500 \mathrm{ml}$ acetone then stirred for 15 min in high electric blender after stoppering the container tightly.

Several experimental tests were done to chose the suitable concentrations in which they were 3, 4, 5\% for all the plant extract used in the study.

Also, some pulp of sour orange fruit were squeezed without seeds and were extracted by petroleum ether solvent following the previous method. Each solvent was then evaporated by using electric fan until dryness.

The scientific and English name of the plants used and their parts are shown in the following table:

\begin{tabular}{|c|c|c|}
\hline Scientific name & English name & Part used \\
\hline Citrus aurantium v. amara & Sour orange & Pulp \\
\hline Lantana sa/vifolia & Lantana & Leaves \\
\hline Geranium robertianum & Herb Robert & leaves \\
\hline
\end{tabular}

\section{Laboratory trial:}

Samples of infested croton leaves were collected randomly from infested shrubs (each consisted of 8 leaves / treatment), kept in paper bags and transferred to the laboratory. Leaves were sprayed by using the previous mentioned concentrations (3, 4, and $5 \%$ ) for the four plant extracts used in the study. Treated leaves were kept in a paper envelopes and insepectation was conducted every 48 hours by counting the different stages of $P$. citri by the aid of stereomicroscope. Also, a pre count was taken for each treatment as in index.

\section{Statistical analysis:}

Reduction percentages were calculated in all treatments according to Stafford and Summers (1963) equation: 
$\%$ reduction $=$ Pretreatment count - Post treatment count $X 100$

Pretreatment count

If (F) values were significant, calculated and L.S.D. were calculated by the aid of Costat computer program.

\section{Estimation of $\mathbf{L T}_{\mathbf{5 0}}$ :}

Laboratory experiments were conducted to clarify the toxic effect of the extracts. The total number of samples were divided in 4 replicates. $\mathrm{LT}_{50}$ values at $5 \%$ confidence limits and slope regression lines were represented and interpreted using probit analysis statistical method of Litchfield and Willcoxon (1949).

\section{RESULTS AND DISCUSSION}

\section{Effect of assayed materials:}

Results in Table (1), showed that the pre spraying counts ranged between $39.75-123$, $45-123$ and $28.5-52$ for all treatments at different concentrations 3, 4 and 5\%, respectively. Also, all results indicated that all treatments of plant extracts caused significant differences among them in three concentrations used.

Data in Table (2), indicated that lantana in acetone caused the higher percentage reductions which recorded throughout period of inspection from 2 days to 8 days ranged from $(34.59-79.84 \%)$, (38.1 - 90.48\%) and (32.69 - 92.30\%) for concentrations 3,4 and $5 \%$, respectively, followed by sour orange extract in petroleum ether causing $(12.98-87.78 \%),(35.65-88.7 \%)$ and $(55.22-97.01 \%)$ for the experimental concentrations used. While, the remaining treatments may be arranged descendingly order as Herb Robert extract in water (10.67-79.78\%), (55.56-88.8\%) and $(28.07-92.98 \%)$ for 3,4 and $5 \%$, respectively. The next was sour orange extract in water $(7.72-91.46 \%),(26.82-85.37 \%)$ and $(29.11-87.34 \%)$, respectively. Statistically analysis in Table (1) revealed differences in responses to all treatment of plant extracts that proved highly significant among different concentrations.

\section{$\mathbf{L T}_{\mathbf{5 0}}$ assessment:}

$\mathrm{LT}_{50}$ values - recorded after treating with the assayed materials - at $4 \%$ concentration were tabulated in Table (3) and illustrated in Fig (1). The shortest $L T_{50}$ value (highest efficacy) was obtained from treatment by Herb Robert extracted in water; 2.32 days. Intermediate values recorded from lantana extracted in acetone; 2.56 days and sour orange extracted in petroleum ether 2.70 days. While the least efficacy - longest LT50 value - was obtained from sour orange extracted in water; 3.75 days. 
514 EFFECT OF SOME PLANT EXTRACTS ON CITRUS MEALY BUG PLANOCOCCUS CITRI (RISSO) 
516 EFFECT OF SOME PLANT EXTRACTS ON CITRUS MEALY BUG PLANOCOCCUS CITRI (RISSO) 
Table 3. $\mathrm{LT}_{50}$ values for Planococcus citri larval feeding on maize plants treated by $4 \%$ concentration of different materials

\begin{tabular}{|c|c|c|c|c|}
\hline \multirow[b]{2}{*}{ Treatments } & \multirow[b]{2}{*}{$\mathrm{LT}_{50}$ days at $4 \%$} & \multirow[b]{2}{*}{ Slope } & \multicolumn{2}{|c|}{ Confidence limits 0.05} \\
\hline & & & $\mathrm{LT}_{50}$ & Slope \\
\hline Herb Robert extracted in water & 2.32 & 1.81 & - & - \\
\hline Lantana extracted in acetone & 2.56 & 3.02 & - & - \\
\hline Sour orange extracted in Petroleum ether & 2.70 & 2.98 & - & - \\
\hline Sour orange extracted in water & 3.75 & 3.17 & 3.36 & 4.14 \\
\hline
\end{tabular}

These results were found in agreement with these obtained by Ibrahim et al., (2001) stated that the monoterpene limonene showed deterrent and insecticide properties, which might used in pest control in organic agriculture. Hollingsworth (2005) who mentioned that aqueous solution of $1 \%$ Limonene against mealy bugs and scale insects in which it achieved acceptable results ranging 69 to $100 \%$ reductions. Also, Mesbah et al., (2009) used five plant extracts against Icerya seychellarum (West.) and they found that camphor and rose extracts were superior reductions against mealy bug. Cloy et al., (2009) mentioned that cotton seed, cinnamon and rosemary extracts caused $90 \%$ mortality to citrus mealy bugs. 


\section{REFERENCES}

1. Awadallah, W.H., A.F. Lutfallah and Y.H. Fayed. 1984. Effect of spraying corn with water extracts of certain aromatic plants on the population of Sesamia cretica Led. and the main predators in corn fields, Agric. Res. Rev. 62(1): 47 - 52.

2. Bakr, E.M. 2010. ehabsoft.com/ Idpline / Download Form.htm

3. Cloy R.A., C.L Galle, S.R. Keith, N.A. Kalscheur and K.E. Kemp. 2009. Effect of commercially available plant derived essential oil products on Arthropod pest. J. of Econ. Entomol., 102(4): 1567 - 1579.

4. El-Sayed, E.I. 1982. Neem $A$. indica seeds as antifeedant and ovipositional repellent for the Egyptian cotton leafworm Spodoptera littoralis (Biosd.) Bull. Ent. Soc. Egypt, Econ. Ser., (49): 49 - 58.

5. Emara, M.M., A.G. El-Sisi and S.A. Mahmoud. 1994. Formulation and evaluation of certain local natural products against Varroa, a mite infesting bee colonies. J. Agric. Sci. Mansoura Univ., 19(5): $1843-1850$.

6. Hollingoworth, R.G. 2005. Limonene, a citrus extracts for control of mealy bugs and scale insects. J. of Econ. Enomol., 98(3): 772 - 779.

7. Ibrahim, M.A., P. Kainulainen, A. Aflatuni and J. K. Holopainen 2001. Inseticidal, repellent, antimicrobial activity and phytoxicity of essential oils: with special reference to limonene and its suitability for control of insect it pests. Agric. and Food Sci. in Finland, 10: 243 - 259.

8. Litchfield, J.T. and F. Willcoxan. 1949. A simplified method of evaluating dose effect experiment. J. Phamacol. And Exp. Therap. 96: 99 - 113.

9. Stafford, E.M. and F.M. Summers. 1963. Evaluation control of San Jose scale. Hilgardaia, 35(2): $13-32$.

10. Yacoub, Sh.S., Amany S. El-Hefny, and Rasha A. El-Hosary. 2010. Evaluation of some compounds from plant origin for controlling Sesamia cretica led. in maize under field conditions. Egypt. J. Agric. Res., 88(1). 


\section{تأثير بعض المستخلصات النباتية على بث الموالح الدقيقى}

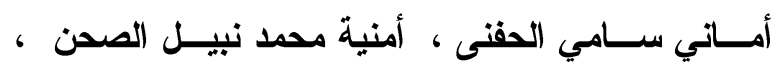

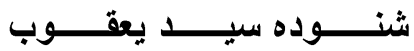

$$
\text { معهُ بحوث وقـاية النباتات - مركز البحــوث الزراعيــة - الدقى - جيزة }
$$

تم دراسة تأثثر مستخلص لب ثمار النارنج فى المــاء والبتروليم ايثز، ومستخلص وأوراق اللانتانا فى

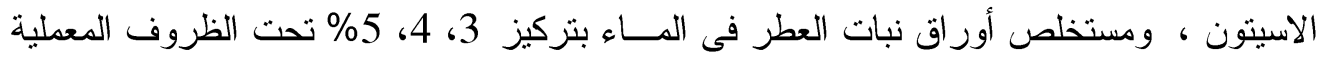

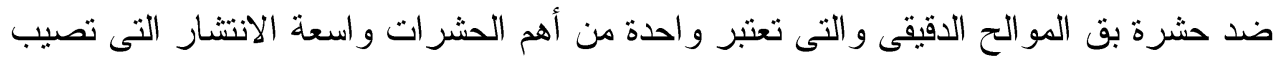
محاصيل الزينة داخل وخارج الصوب.

و أوضحت النتائج ان مستخلص لب ثمار النارنج فى البتروليم ايثر أعلى نسبة خفض فى تعداد أفراد

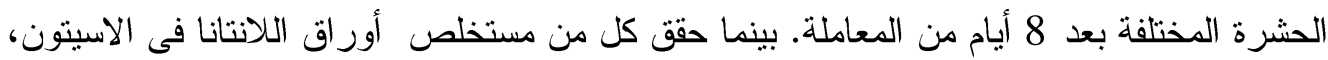

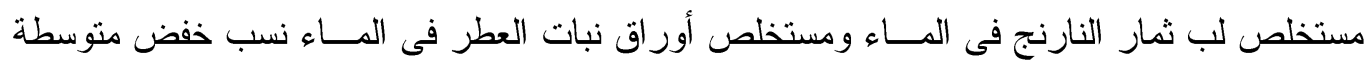

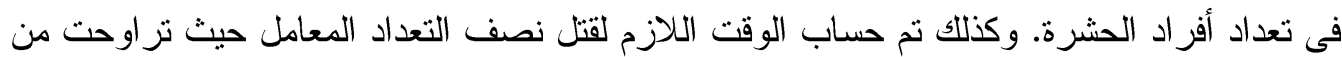
2.32 الى 3.75 يوم لكل من مستخلص أوراق نبات العطر فى المـاء ومستخلص لب ثمار النارنج فى المــاء على التزتيب. 